\section{\& PRODUKTIVITAS KERJA}

Segala puji senantiasa kita panjatkan kehadirat Allah Swt, atas segala rahmat dan karunianya, akhirnya penulis dapat menyelesaikan penyusunan buku yang berjudul "PROFESIONALISME GURU DAN PRODUKTIVITAS KERJA". Saya menyadari bahwa tanpa bantuan dan bimbingan dari berbagai pihak sangatlah sulit bagi saya untuk menyelesaikan karya ini. Oleh karena itu, saya mengucapkan banyak terima kasih pada semua pihak yang telah membantu penyusunan buku ini. Sehingga buku ini bisa hadir di hadapan pembaca.

Tinggi rendahnya kualitas guru atau tenaga pendidik antara lain ditandai dengan adanya unsur kreatifitas dan produktivitas yang direalisasikan dengan kinerja individu maupun kelompok dalam organisasi sekolah. Produktivitas kerja guru yang optimal dapat tercapai dengan faktor utamanya apabila para guru memiliki kemampuan profesional yang memadai serta didukung oleh lingkungan kerja yang baik.

Dalam buku ini membahas mengenai pengaruh profesionalisme guru dan lingkungan kerja yang signifikan terhadap produktivitas kerja guru di SMK Negeri 3 Jakarta, untuk mengetahui variabel yang paling dominan berpengaruh terhadap produktivitas kerja guru di SMK Negeri 3 Jakarta. Selain itu, buku ini juga membahas tentang studi mengenai profesionalisme guru, gambaran umum sekolah, penelitian karakteristik guru, analisis data serta faktor penentu produktivitas kerja guru di SMK Negeri 3 Jakarta.
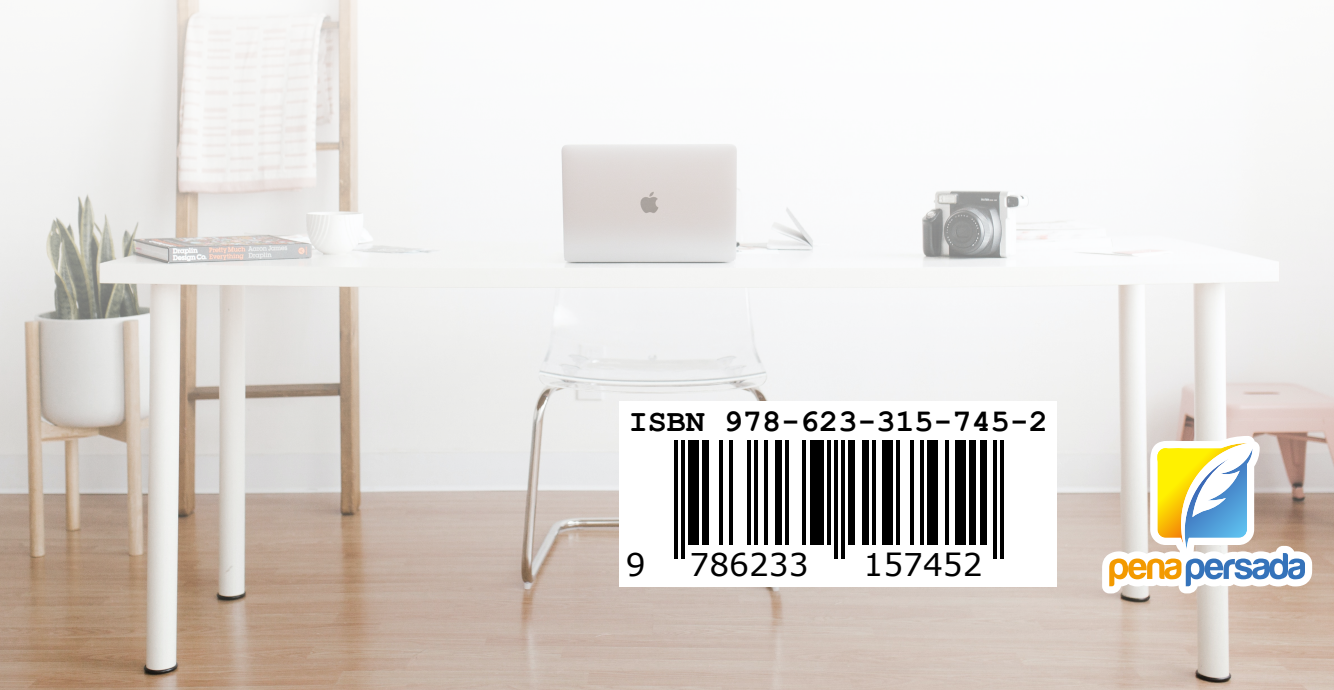

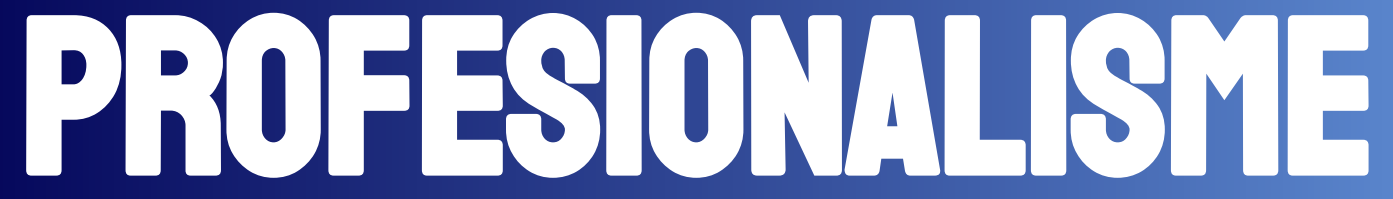
GURU

e

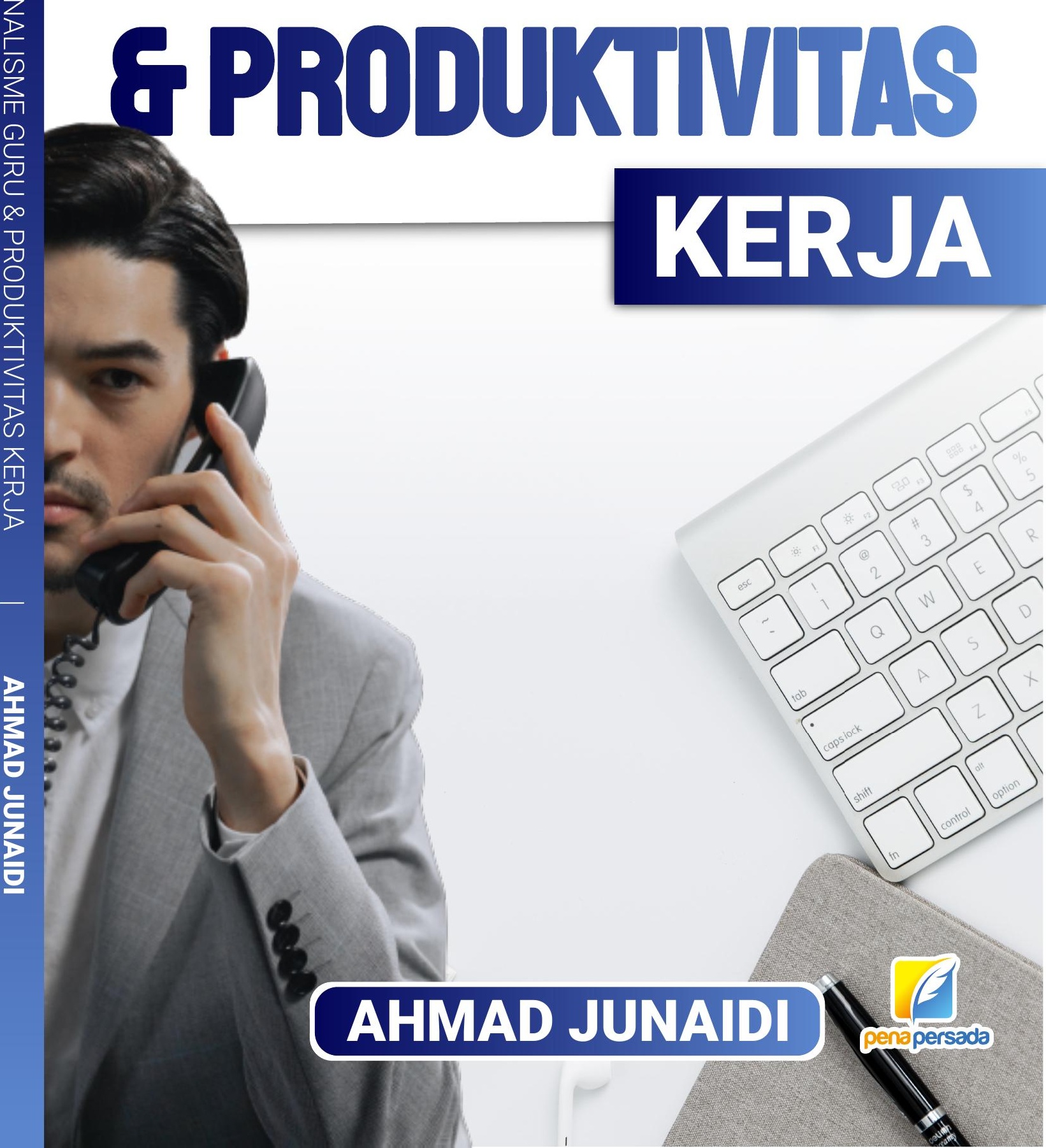




\section{PROFESIONALISME GURU \\ DAN PRODUKTIVITAS KERJA}

AHMAD JUNAIDI

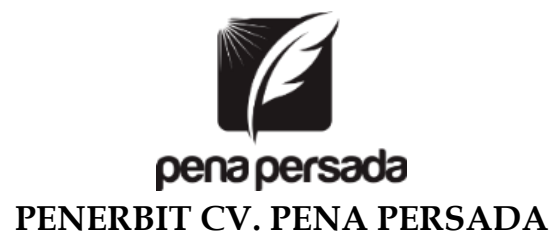




\title{
PROFESIONALISME GURU \\ DAN PRODUKTIVITAS KERJA
}

\author{
Penulis: \\ Ahmad Junaidi \\ ISBN : 978-623-315-745-2
}

Editor:

Wiwit Kurniawan

Design Cover :

Arsyie Kania Rakhma

Layout :

Nofendy Ardyanto

\section{Penerbit CV. Pena Persada \\ Redaksi :}

Jl. Gerilya No. 292 Purwokerto Selatan, Kab. Banyumas

Jawa Tengah

Email : penerbit.penapersada@gmail.com

Website : penapersada.com Phone : (0281) 7771388

Anggota IKAPI

All right reserved

Cetakan pertama : 2021

Hak Cipta dilindungi oleh undang-undang. Dilarang memperbanyak karya tulis ini dalam bentuk apapun tanpa izin penerbit 


\section{KATA PENGANTAR}

Segala puji senantiasa kita panjatkan kehadirat Allah Swt, atas segala rahmat dan karunianya, akhirnya penulis dapat menyelesaikan penyusunan buku yang berjudul "PROFESIONALISME GURU DAN PRODUKTIVITAS KERJA". Saya menyadari bahwa tanpa bantuan dan bimbingan dari berbagai pihak sangatlah sulit bagi saya untuk menyelesaikan karya ini. Oleh karena itu, saya mengucapkan banyak terima kasih pada semua pihak yang telah membantu penyusunan buku ini. Sehingga buku ini bisa hadir di hadapan pembaca.

Tinggi rendahnya kualitas guru atau tenaga pendidik antara lain ditandai dengan adanya unsur kreatifitas dan produktivitas yang direalisasikan dengan kinerja individu maupun kelompok dalam organisasi sekolah. Produktivitas kerja guru yang optimal dapat tercapai dengan faktor utamanya apabila para guru memiliki kemampuan profesional yang memadai serta didukung oleh lingkungan kerja yang baik.

Dalam buku ini membahas mengenai pengaruh profesionalisme guru dan lingkungan kerja yang signifikan terhadap produktivitas kerja guru di SMK Negeri 3 Jakarta, untuk mengetahui variabel yang paling dominan berpengaruh terhadap produktivitas kerja guru di SMK Negeri 3 Jakarta

Penulis menyadari bahwa buku ini masih jauh dari kesempurnaan. Oleh karena itu kritik dan saran yang membangun sangat dibutuhkan guna penyempurnaan buku ini. Akhir kata saya berharap Allah Swt berkenan membalas segala kebaikan semua pihak yang telah membantu

Penulis 


\section{DAFTAR ISI}

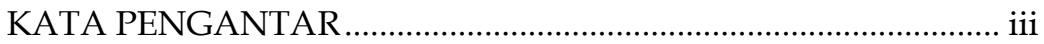

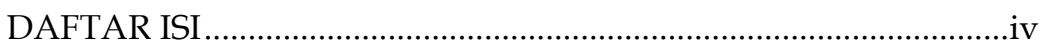

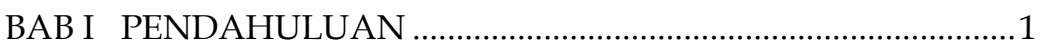

BAB II PROFESIONALISME GURU ................................................. 5

A. Definisi Profesionalisme Guru ........................................

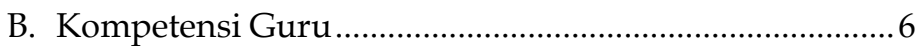

BAB III LINGKUNGAN KERJA DAN PRODUKTIVITAS KERJA 9

A. Lingkungan Kerja.............................................................

B. Produktivitas Kerja ........................................................... 11

BAB IV STUDI MENGENAI PROFESIONALISME GURU ...........15

A. Studi Terdahulu ...............................................................15

B. Hubungan antara Profesionalisme guru, Lingkungan kerja, dan Produktivitas Kerja .........................................16

1. Profesionalisme guru berpengaruh terhadap produktivitas kerja guru...............................................16

2. Lingkungan kerja berpengaruh terhadap produktivitas kerja guru..............................................16

3. Profesionalisme guru dan lingkungan kerja bersama-sama berpengaruh terhadap produktivitas kerja guru.

BAB V GAMBARAN UMUM SEKOLAH ........................................19

A. Sejarah Singkat Sekolah Menengah Kejuruan

Negeri 3 Jakarta .......................................................... 19

B. Struktur Organisasi dan Uraian Pekerjaan..................... 20

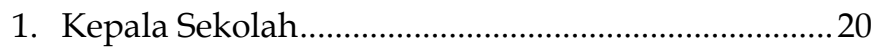

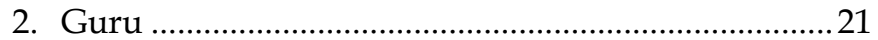

3. Ketua Program Keahlian ............................................ 22

4. Kepala Urusan Perpustakaan .......................................23

5. Kasubag Tata Usaha......................................................24

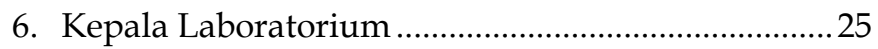

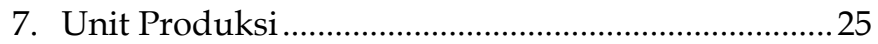




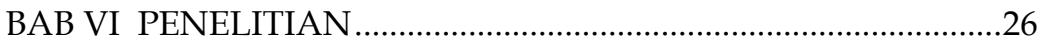

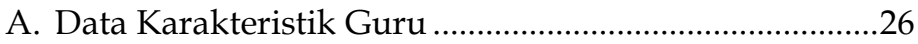

1. Karakterirtik Menurut Jenis Kelamin .........................26

2. Karakteristik Menurut Umur ......................................26

3. Karakteristik Menurut Pendidikan ............................27

4. Karakteristik Menurut Masa Kerja ...............................27

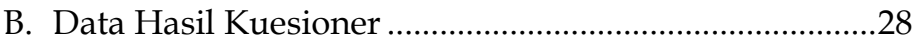

1. Hasil Kuesioner Terhadap Profesionalisme Guru ..28

2. Hasil Kuesioner Terhadap Lingkungan Kerja ..........30

3. Hasil Kuesioner Terhadap Produktivitas Kerja

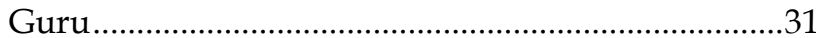

4. Hasil Uji Kualitas Instrumen.......................................33

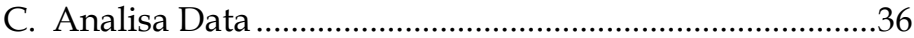

D. Faktor Penentu produktivitas kerja guru di SMK Negeri 3 Jakarta...........................................................

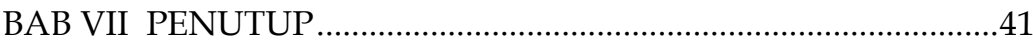




\section{PROFESIONALISME GURU DAN PRODUKTIVITAS KERJA}




\section{BAB I PENDAHULUAN}

Pendidikan selalu mengalami pembaharuan dalam rangka mencari struktur kurikulum, sistem pendidikan dan metode pengajaran yang efektif dan efisien. Upaya tersebut antara lain peningkatan sarana dan prasarana, peningkatan mutu para pendidik dan peserta didik serta perubahan dan perbaikan kurikulum. Pendidikan yang mampu mendukung pembangunan di masa mendatang adalah pendidikan yang mampu mengembangkan potensi peserta didik, sehingga yang bersangkutan mampu memiliki dan memecahkan problema pendidikan yang dihadapinya. Pendidikan harus menyentuh potensi nurani maupun potensi kompetensi peserta didik. Konsep pendidikan tersebut terasa semakin penting ketika seseorang harus memasuki kehidupan di masyarakat dan dunia kerja, karena yang bersangkutan harus mampu menerapkan apa yang dipelajari di sekolah untuk menghadapi problema yang dihadapi dalam kehidupan sehari-hari saat ini maupun yang akan datang.

Sekolah sebagai suatu institusi atau lembaga pendidikan idealnya harus mampu melakukan proses edukasi, sosialisasi, dan transformasi. Dengan kata lain, sekolah yang bermutu adalah sekolah yang mampu berperan sebagai proses edukasi (proses pendidikan yang menekankan pada kegiatan mendidik dan mengajar), proses sosialisasi (proses bermasyarakat terutama bagi anak didik), dan wadah proses transformasi (proses perubahan tingkah laku ke arah yang lebih baik/lebih maju). Peningkatan kualitas pendidikan merupakan suatu proses yang berintegrasi dengan proses peningkatan kualitas sumber daya manusia itu sendiri. Secara umum diantara faktor yang mempengaruhi kualitas pendidikan adalah : 
1. Tersedianya sarana dan prasarana yang memadai untuk terlaksananya proses belajar mengajar.

2. Kebijakan pemerintah yang berhubungan dengan pelaksanaan kegiatan pembelajaran.

3. Kualitas guru sebagai ujung tombak terlaksananya kegiatan pembelajaran.

Dalam melaksanakan tugas dan tanggung jawab tersebut, seorang guru dituntut memiliki beberapa kemampuan dan keterampilan tertentu. Kemampuan dan keterampilan tersebut sebagai bagian dari kompetensi profesionalisme guru. Kompetensi merupakan suatu kemampuan yang mutlak dimiliki oleh guru agar tugasnya sebagai pendidik dapat terlaksana dengan baik. Sejalan dengan hal itu, untuk mendukung terwujudnya proses belajar mengajar yang berkualitas di sekolah diperlukan adanya guru yang profesional. Kemampuan atau profesionalisme guru menurut pendapat Usman (2002) meliputi hal-hal berikut ini:

1. Menguasai landasan kependidikan

2. Menguasai bahan pengajaran

3. Menyusun program pengajaran

4. Melaksanakan program pengajaran

5. Menilai hasil belajar mengajar yang telah dilaksanakan

Guru yang bekerja secara efektif ialah guru yang memberikan peluang-peluang maksimal kepada peserta didik untuk belajar dan mengembangkan potensi yang dimilikinya, serta mampu menciptakan iklim kondusif bagi siswa untuk belajar dengan baik dan berhasil. Hal dipengaruhi salah satunya oleh lingkungan kerja di mana guru tersebut melakukan kegiatan belajar mengajar. Pengertian lingkungan kerja menurut Nitisemito (2000) kerja adalah segala sesuatu yang ada di sekitar para pekerja dan dapat mempengaruhi dirinya dalam menjalankan tugas yang di bebankan. Apabila lingkungan kerja baik maka hal tersebut dapat memberikan 
pengaruh yang positif terhadap kinerja karyawan, begitu pula sebaiknya.

Sedarmayanti (2001) menyatakan bahwa lingkungan kerja adalah keseluruhan alat perkakas dan bahan yang dihadapi, lingkungan sekitarnya dimana seseorang bekerja, metode kerjanya, serta pengaturan kerjanya baik sebagai perseorangan maupun sebagai kelompok. Hal ini menekankan bahwa lingkungan kerja akan menentukan apa yang akan guru lakukan di organisasi sekolah. Lingkungan kerja di sekolah dikatakan baik atau sesuai apabila setiap manusia (guru, murid, komponen sekolah lainnya) dapat melaksanakan kegiatan secara optimal, sehat, aman, dan nyaman. Kesesuaian lingkungan kerja dapat dilihat akibatnya dalam jangka waktu yang lama, dan lebih jauh lagi lingkungan kerja sekolah yang kurang baik dapat menuntut tenaga kerja dan waktu yang lebih banyak serta tidak diperolehnya rancangan sistem kerja yang efektif dan efisien di sekolah.

Tinggi rendahnya kualitas guru atau tenaga pendidik antara lain ditandai dengan adanya unsur kreatifitas dan produktivitas yang direalisasikan dengan kinerja individu maupun kelompok dalam organisasi sekolah. Produktivitas kerja menurut Rivai (2006) merupakan perilaku nyata yang ditampilkan setiap orang sebagai prestasi kerja yang dihasilkan oleh karyawan sesuai dengan perannya dalam perusahaan. Pengertian tersebut berarti bahwa dengan hasil kerja yang dicapai oleh seorang karyawan (guru) dalam melakukan suatu pekerjaan dapat dievaluasi tingkat produktivitasnya, dengan demikian kinerja karyawan harus dapat ditentukan dengan pencapaian target selama periode waktu yang dicapai organisasi (sekolah).

Perlu disadari bahwa keinginan untuk berprestasi merupakan salah satu kebutuhan bagi setiap manusia, baik itu buruh, majikan maupun masyarakat perlu berprestasi. Prestasi yang baik akan mencerminkan kinerja yang baik pula. Kinerja yang baik merupakan cermin keberhasilan pengelola tenaga 
kerja oleh suatu organisasi, untuk itulah diperlukan suatu usaha untuk mengembangkan setiap potensi yang ada dalam diri manusia agar tercapai efektifitas dan produktifitas kerja yang baik.

Dalam tataran konsep, produktivitas kerja guru yang optimal hanya mungkin tercapai dengan faktor utamanya apabila para guru memiliki kemampuan profesional yang memadai serta didukung oleh lingkungan kerja yang baik. 


\section{BAB II \\ PROFESIONALISME GURU}

\section{A. Definisi Profesionalisme Guru}

Guru sebagai bagian dari tenaga kependidikan memiliki kedudukan yang sangat penting dalam pencapaian tujuan pendidikan di sekolah. Pengertian guru menurut Undang-Undang No. 14 Tahun 2005 tentang Guru dan Dosen, yakni sebagaimana tercantum dalam Bab I Ketentuan Umum pasal 1 ayat (1), guru adalah pendidik profesional dengan tugas utama mendidik, mengajar, membimbing, mengarahkan, melatih, menilai, dan mengevaluasi peserta didik pada pendidikan dasar dan menengah.

Adapun kata profesional sebagaimana tertuang dalam Undang Undang RI No. 14 Tahun 2005 tentang Guru dan Dosen, pasal 1 butir 4 menyebutkan bahwa profesionalisme adalah pekerjaan atau kegiatan yang dilakukan oleh seseorang dan menjadi sumber penghasilan kehidupan yang memerlukan keahlian, kemahiran, dan kecakapan yang memenuhi standar mutu atau norma tertentu serta memerlukan pendidikan profesi.

Dengan demikian pengertian profesional guru sebagaimana dikemukakan oleh Usman (2002) adalah orang yang memiliki kemampuan dan keahlian khusus dalam bidang keguruan sehingga ia mampu melakukan tugas dan fungsinya sebagai guru dengan kemampuan maksimal. Tujuan lembaga sekolah dapat dicapai secara maksimal apabila tenaga guru memiliki kompetensi-kompetensi yang telah ditetapkan yang meliputi kompetensi pedagogik, kompetensi sosial, kompetensi professional dan kompetensi kepribadian. 
Tilaar (2002) menjelaskan pula bahwa seorang profesional menjalankan pekerjaannya sesuai dengan tuntutan profesi atau dengan kata lain memiliki kemampuan dan sikap sesuai dengan tuntutan profesinya. Seorang profesional menjalankan kegiatannya berdasarkan profesionalisme, dan bukan secara amatiran. Profesionalisme bertentangan dengan amatirisme. Seorang profesional akan terus-menerus meningkatkan mutu karyanya secara sadar, melalui pendidikan dan pelatihan.

Guru profesional menurut Danim (2002) adalah guru yang memiliki kompetensi tertentu sesuai dengan persaratan yang dituntut oleh profesi keguruan. Dengan demikian guru profesional adalah guru yang senantiasa menguasai bahan atau materi pelajaran yang akan diajarkan dalam interaksi belajar mengajar, serta senantiasa mengembangkannya kemampuannya secara berkelanjutan, baik dalam segi ilmu yang dimilikinya maupun pengalamannya. Menurut Sholeh (2006) menyatakan bahwa dalam proses pendidikan, guru tidak hanya menjalankan fungsi alih ilmu pengetahuan (transfer of knowledge), tapi juga berfungsi untuk menanamkan nilai (values) serta membangun karakter (character building) peserta didik secara berkelanjutan.

\section{B. Kompetensi Guru}

Kompetensi yang harus dimiliki oleh guru dapat mencakup kompetensi pedagogik, kompetensi kepribadian, kompetensi sosial, dan kompetensi profesional. Kompetensi pedagogik adalah berkaitan dengan kemampuan mengelola pembelajaran, sedang kompetensi kepribadian adalah kemampuan pribadi yang mantap, berakhlak mulia, arif, dan berwibawa serta menjadi teladan peserta didik. Kompetensi sosial berkaitan dengan kemampuan hubungan antar pribadi dan dalam kehidupan bermasyarakat. Sedangkan, kompetensi professional adalah kemampuan 
dalam penguasaan materi pembelajaran dan bidang keahliannya. Guru yang mempunyai kompetensi profesional akan terlihat dalam pelaksanaan tugas dan tanggung jawabnya di sekolah tempat ia bekerja.

Kemampuan atau profesionalitas guru menurut pendapat Usman (2002) meliputi hal-hal berikut ini:

1. Menguasai landasan kependidikan

a. Memahami tujuan pendidikan nasional untuk mencapai tujuan

b. Memahami fungsi sekolah dalam masyarakat

c. Mengenal prinsip-prinsip psikologi pendidikan yang dapat dimanfaatkan dalam proses belajar mengajar.

2. Menguasai bahan pengajaran

a. Mengusai bahan pengajaran sesuai kurikulum pendidikan

b. Mengusai bahan pengayaan pembelajaran

3. Menyusun program pengajaran

a. Menetapkan tujuan pembelajaran

b. Memiliki dan mengembangkan bahan pembelajaran

c. Memiliki dan mengembangkan media pengajaran yang sesuai

4. Melaksanakan program pengajaran

a. Menciptakan iklim belajar mengajar yang tepat

b. Mengatur ruangan belajar

c. Mengelola intraksi belajar mengajar

5. Menilai hasil belajar mengajar yang telah dilaksanakan

a. Menilai prestasi siswa untuk kepentingan pengajaran

b. Menilai proses belajar mengajar yang telah dilaksanakan.

Menyoroti kompetensi profesional guru memang membutuhkan penjabaran dan deskripsi yang jelas agar memperoleh gambaran yang utuh menyeluruh mengenai konsep kompetensi professional tersebut. Kompetensi yang dimiliki guru harus searah dengan kebutuhan pendidikan di 
sekolah (kurikulum), tuntutan masyarakat, dan perkembangan ilmu pengetahuan dan teknologi. Berdasarkan uraian di atas, maka dapat disimpulkan bahwa kompetensi profesional merupakan satu kesatuan yang utuh yang menggambarkan potensi, pengetahuan, keterampilan, dan sikap yang dinilai, yang terkait dengan profesi guru yang berkenaan dengan bagian-bagian yang dapat diaktualisasikan dan diwujudkan dalam bentuk tindakan atau kinerja untuk menjalankan profesi guru. 


\section{BAB III \\ LINGKUNGAN KERJA DAN \\ PRODUKTIVITAS KERJA}

\section{A. Lingkungan Kerja}

Setiap perusahaan selalu berusaha untuk menciptakan lingkungan kerja yang menyenangkan, karena akan berpengaruh terhadap peningkatan kinerja perusahaan dalam menjalankan kegiatannya selalu memperhatiakan faktor-faktor yang ada dalam perusahaan, juga harus memperhatikkan faktor-faktor yang ada diluar perusahaan atau lingkungan sekitarnya. Untuk mendapatkan gambaran yang jelas mengenai pengertian lingkungan kerja berikut ini dikemukakan beberapa pendapat menurut pendapat para ahli yang berkompeten.

Menurut Indrafachrudi (1994) lingkungan kerja adalah segala sesuatu yang ada disekitar pekerja yang dapat mempengaruhi dalam berkerja meliputi pengaturan penerangan, pengontrolan suara gaduh, pengaturan kebersihan tempat kerja dan pengaturan keamanan tempat kerja. Pendapat lain dikemukakan oleh Nitisemito (2000) bahwa lingkungan kerja adalah segala sesuatu yang ada di sekitar para pekerja dan dapat mempengaruhi dirinya dalam menjalankan tugas yang di bebankan.

Dari pendapat di atas dapat disimpulkan bahwa lingkungan kerja adalah segala sesuatu yang ada di sekitar para pekerja yang mempengaruhi tugas- tugas yang di bebankan, namun secara umum pengertian lingkungan kerja adalah merupakan lingkungan dimana para karyawan tersebut melaksanakan tugas dan pekerjaannya. Sedarmayanti (2001) menyatakan bahwa secara garis besar, jenis lingkungan kerja terbagi menjadi 2 yaitu : 


\section{Lingkungan kerja Fisik}

Lingkungan kerja fisik adalah semua keadaan yang berbentuk fisik yang terdapat disekitar tempat kerja yang dapat mempengaruhi karyawan baik secara langsung maupun tidal langsung. Diantaranya penerangan, ruangan kerja, fasilitas kerja, ventilasi udara dll.

2. Lingkungan kerja Non Fisik

Lingkungan kerja non fisik adalah semua keadaan yang terjadi yang berkaitan dengan hubungan kerja baik hubungan dengan atasan maupun hubungan sesama rekan kerja, ataupun hubungan dengan bawahan. Diantaranya keamanan dan kenyamanan kerja, dan pelayanan tenaga kerja.

Organisasi dapat berkembang merupakan keinginan setiap individu yang berada dalam organisasi tersebut, sehingga diharapkan dengan perkembangan tersebut organisasi mampu bersaing dalam mengikuti perkembangan zaman. Karena itu, tujuan yang diharapkan oleh organisasi dapat tercapai dengan baik. Kemajuan organisasi di pengaruhi oleh faktor-faktor lingkungan yang bersifat intenal dan eksternal. sejauhmana tujuan organisasi telah tercapai dapat dilihat dari seberapa besar perusahaan memenuhi tuntutan lingkungannya

Lingkungan yang baik untuk bekerja akan menimbulkan perasaan kerasan dna betah dalam bekerja. Sebaliknya lingkungan yang kacau, kotor, tidak teratur, hiruk pikuk akan menimbulkan keengganan untuk bekerja dan tidak mungkin akan mencapai konsentrasi yang tinggi dalam bekerja, bahkan yang terjadi adalah kekacauan, dan perasaaan mudah letih. Kinerja yang baik selalu berusaha untuk tepat waktu, efektif dan efisien, menetapkan aturanaturan dan kebiasaan-kebiasaan yang harus dipenuhi bersama, serta menciptakan lingkungan kerja yang baik. 
Dari pengertian tentang lingkungan kerja seperti diuaraikan diatas, maaka dapat disimpulkan bahwa lingkungan kerja adalah keadaan dimana tempat kerja yang baik meliputi fisik atau non fisikyang dapat memberikan kesan menyenangkan, aman, tentram dan lain sebagainya. Apabila lingkungan kerja baik maka hal tersebut dapat memacu timbulnya rasa puas dalam diri karyawan yang pada akhirnya dapat memberikan pengaruh positif terhadap kinerja karyawan, begitu sebaliknya, apabila lingkungan kerja buruk maka karyawan tidak akan mempunyai kepuasan dalam bekerja.

\section{B. Produktivitas Kerja}

Peranan sumber manusia daya dalam organisasi apapun bentuknya sangat penting kerena sebagai penggerak utama seluruh kegiatan atau aktivitas perusahaan dalam mencapai tujuannya, baik untuk memperoleh keuntungan maupun untuk mempertahankan kelangsungan hidup perusahaan. Berhasil tidaknya suatu perusahaan dalam mempertahankan eksitensi perusahaan dimulai dari manusia itu sendiri dalam mempertahankan perusahaan dalam meningkatkan afektivitas dan efisiensi secara maksimal. Kinerja sumber daya manusia merupakan gambaran tingkat pencapaian pelaksanaan suatu kegiatan/program dalam mewujudkan sasaran, tujuan, misi dan visi organisasi.

Kusriyanto (1997), menyatakan produktivitas tenaga kerja adalah perbandingan antara hasil yang dicapai dengan peran serta tenaga kerja per satuan waktu (lazimnya per jam orang), maka dalam hal ini produktivitas individu mendapat perhatian cukup besar, sebagai sumber masukan dalam melakukan kegiatan yang menentukan efektifitas,

efisiensi, kualitas, dan produktivitas. Sedangkan menurut Ravianto (2000) produktivitas adalah rasio atau perbandingan antara pengeluaran (output) yang dihasilkan 
oleh berbagai elemen masukan (input) dibagi dengan masukan itu sendiri yang digunakan untuk menghasilkan keluaran. Lebih lanjut Ravianto (2000) mengatakan efektivitas mengarah kepada pencapaian hasil unjuk kerja yang maksimal, berkaitan dengan kualitas, kuantitas, dan waktu. Sedangkan efisiensi, berkaitan dengan upaya membandingkan input dengan realisasi penggunaanya atau bagaimana pekerjaan itu dilaksanakan. Untuk lebih jelasnya sebagai berikut :

1. Efisiensi merupakan suatu ukuran dalam membandingkan input yang direncanakan dengan input yang sebenarnya. Dengan penghematan yang lebih besar, maka efisiensi akan menjadi lebih tinggi, sebaliknya semakin kecil input yang dapat dihemat, berarti terjadi kurang efisien (tingkat efisiensinya rendah)

2. Efektivitas merupakan ukuran yang memberikan gambaran seberapa jauh target dapat dicapai, berarti lebih berorientasi pada keluaran, sedang penggunaan masukan tidak menjadi perhatian utama.

3. Kuantitas merupakan suatu ukuran yang menyatakan seberapa jauh telah terpenuhi berbagai persyaratan, spesifikasi, dan harapan. Kualitas berkaitan dengan proses produksi yang berpengaruh pada kualitas hasil yang dicapai secara keseluruhan.

Berdasarkan beberapa pendapat ahli mengenai produktivitas kerja dan faktor-faktor yang mempengaruhinya, dapat menyimpulkan bahwa kinerja pegawai akan efektif apabila memperhatikan faktor-faktor yang dapat mempengaruhinya, dan ini berarti bahwa upaya untuk mengembangkan kinerja pegawai kearah yang diinginkan oleh organisasi sesuai dengan kebutuhan organisasi dan tuntutan perubahan, jelas menuntut pencermatan akan faktor-fakor tersebut, baik itu faktor dari dalam (intern) individu itu sendiri maupun faktor ekstern. 
Hal inipun berlaku dalam kaitannya dengan kinerja inovatif, dimana jika kinerja inovatif ingin ditumbuh kembangkan dalam suatu organisasi, maka kondisi-kondisi/faktor-faktor yang dapat mempengaruhinya perlu mendapat perhatian, sehingga kebijakan pimpinan dalam organisasi dapat menciptakan kondisi yang kondusif bagi terwujudnya hal tersebut.

Keberhasilan suatu organisasi dalam mencapai tujuan tergantung pada bagaimana para personel dalam melaksanakan pekerjaannya sesuai dengan tugas dan tanggung jawabnya masing-masing. Dalam organisasi sekolah berhasil tidaknya tujuan pendidikan sangat ditentukan oleh kinerja guru, karena tugas utama guru adalah mengelola kegiatan belajar mengajar. Berkenaan dengan kinerja guru sebagai pengajar, menurut Usman (2002), mencakup aspek kemampuan personal, kemampuan profesional dan kemampuan sosial.

Guru merupakan jabatan atau profesi yang memerlukan keahlian khusus sebagai guru. Pekerjaan tersebut tidak dapat dilakukan oleh orang yang tidak memiliki keahlian untuk melakukan kegiatan atau pekerjaan sebagai guru. Guru memiliki dua fungsi istimewa yang sekaligus membedakannya dari pegawai atau pekerja lainnya dalam masyarakat, yakni mengadakan suatu jembatan antara sekolah dengan luar sekolah, serta mengadakan hubungan antara dunia muda dengan dunia dewasa dalam konteks pembelajaran.

Profesi sebagai pengajar menjadikan tugas guru secara langsung menyentuh manusia menyangkut kepentingan dan kebutuhannya untuk tumbuh dan berkembang ke arah kedewasaan dan kemandirian melalui proses pembelajaran. Pengajaran yang dilakukan oleh guru itu dilaksanakan dalam interaksi edukatif antara guru dan murid yaitu antara keadaan internal dan proses kognitif siswa. 